\title{
Different Result of Cognitive Impairment Screening in Adolescent Aged 10-12 Years with Normal and Short Stature in Pangandaran District
}

\author{
Rodman Tarigan*, Meita Dhamayanti, Eddy Fadlyana, Kusnandi Rusmil \\ Department of Child Health, Universitas Padjadjaran, Bandung, Indonesia \\ *Corresponding author: rodmantarigan@yahoo.co.id
}

\begin{abstract}
In Indonesia, the prevalence of short stature in adolescents aged 13-15 years and 16-18 years are respectively $35,1 \%$ and $31,4 \%$. The growth of adolescentsis related in line to the development with the cognitive function. To find out the difference result of cognitive impairment screening in adolescents aged 10-12 years with normal and short stature. This was a cross-sectional analytic study conducted during December 2016 - March 2017 in Pangandaran District, West Java. Body height of the subjects were measured and they answered questions in Mini-Mental State Examination (MMSE) to assess the cognitive function. Data analysis to determine the different results of cognitive impairment screening in adolescent with normal and short stature use statistical Wilcoxon rank sum test. A total of 144 subjects met the inclusion criteria, comprising 45 subjects with short stature and 99 subjects normal. Median (min; max) MMSE scores for adolescent with short stature and normal were $24(14 ; 30)$ and 27 (9; 30). There were significant differences in the median of MMSE scores between adolescents with normal and short stature (median difference $=-2.00$, CI 95\% $(-3.00 ;-0.00), \mathrm{p}=0.013)$. There were significantly different results of this study in cognitive impairment screening in adolescents aged 10-12 years between normal and short stature. The result of cognitive impairment screening in short statured adolescents aged 10-12 yearswas lower compared to those of normal stature adolescents.
\end{abstract}

Keywords: adolescents, normal stature, short stature, cognitive, MMSE

Cite This Article: Rodman Tarigan, Meita Dhamayanti, Eddy Fadlyana, and Kusnandi Rusmil, "Different Result of Cognitive Impairment Screening in Adolescent Aged 10-12 Years with Normal and Short Stature in Pangandaran District.” American Journal of Clinical Medicine Research, vol. 5, no. 3 (2017): 26-30. doi: 10.12691/ajcmr-5-3-1.

\section{Introduction}

Adolescence is a phase where changes, either physical, cognitive, or psychosocial, occur betweenchildhood and adulthood periods. Most adolescents with good health state encounter changes towards adulthood without much hassle. To get through the phase, every child deserves/needs adequate nutrition and good health status for further growth and development process. The lack of nutrition and poor health status may cause delayed growth and development. [1]

Among the various changesduring the adolescence, the most important is the cognitive function change from concrete thinking to formal operational or abstract thinking. During the adolescence, young people are more capable in using symbols to represent objects from reality and articulate abstract concepts. This process occurs as a result of brain maturation, formed by psychosocial interaction. [1]

Growth is the indicator of child health, nutritional status, and genetic background. Child growth is the result of interaction among various factors such as genetic, environment, and hormones. Disorders in any of those factors may cause growth disorder that manifests as short stature or tall stature. Accurate and continuous anthropometric measurement is very important in evaluating child growth. Short stature is a symptom, not a disease. The shorter the child, the more the suspicion on the presence of pathological disorders of the body. Early detection of short stature needs to be done, so that intervention could be done as soon as possible since short stature has an impact to the child's psychosocial, life quality, cost of medical treatment, and environmental facilities needs. [2]

Body weight measurement based on age represent the child's long term nutritional status (chronic). The result of the measurement will then be compared to the World Health Organization (WHO) standard child growth chart to determine the nutritional status. A child with poor nutrition is labelled as underweight, wasted, and stunted, while child excessive nutrition is labelled as overweight. $[3,4]$

Low body weight, thin, and short can be found at the same time and show worse mortality and morbidity rate compared to only one or two of those signs. [5,6]

Data analysis involving 53.767 children from Africa, Asia, and Latin America showed that stunted and underweight children have three times higher mortality rate compared to those of normal nutritional status. [6] 
Compared to other countries, Indonesia has a high prevalence of underweight and stunted children (30-39\%). Indonesia is in the $5^{\text {th }}$ world rank of countries with stunted children. Data from UNICEF in 2011 showed that Indonesia belonged to 5 countries with the highest prevalence of stunting in children under 5 years old: (1) India (61.7 million), (2) Nigeria (11 million), (3) Pakistan (9,6 million), (4) China (8 million), and (5) Indonesia (7.5 million). [7] Nationalwide, based on Riset Kesehatan Dasar 2013, the prevalence of stunting in Indonesia was as much as $37.2 \%, 18 \%$ of which were severely stunted and $19.2 \%$ were stunted. This isan increased number compared to those in 2010, stunting was only $35.6 \%$. [3]

Indonesia isin betterposition compared to India, China, Nigeria, and Pakistan. South East Asia countries such as Myanmar, Vietnam, Malaysia, Thailand, and Singapore which have prevalence of 35\%, 23\%, 17\%, 16\%, and 4\% consecutively. [8]

The total population of adolescents worldwide is approximately 1.2 billion or $18 \%$ of the total world population. According to a survey in Indonesia in 2010, 10-19 years old group was 43.5 million people (about $18 \%$ of the total population). Based on the central statistics of West Java province, children of 10-19 years old group were 7.839 .547 (18\%) of all West Java population (43.227.107). [3]

Based on the national survey in 2013, the prevalence of short stature adolescents were $35.1 \%$ (13.8\% severely stunted, $21.3 \%$ stunted). The prevalence of short stature in boys was highest among the 13 year-olds (40.2\%), while in girls were 11 year old (35.8\%). Data from the same source showed that the prevalence of short stature among children aged 5-12 years was 30.7\%, children aged 13-15 was $35.1 \%$ and children aged $16-18$ was $31.4 \%$. The prevalence of short stature in West Java for children aged 5-12 was $29.6 \%$. Based on those data, it was concluded that the incidence of short stature among adolescents in West Java, Indonesia is high. [3]

Without any intervention, children with short stature will be a burden in the future. The clinical manifestation of children with short stature is high mortality and morbidity rate, linked with the low cognitive, motoric, and language function, and economically may increase the cost for medical needs. [9] Children with short stature is related with the decrease of learning capacity, increased length of study, decreased working capacity, affecting the productivity and may cause low income in the future. Short stature is a predictor of poor human resource quality that is widely acceptable, thus they can decrease a country's productivity in the future. [9] Women who were stunted tend to have stunted offsprings as well, thus, it might cause a new cycle of poverty and lack of human resource quality that is difficult to handle. [10]

Based on a study by Perignon et al in Cambodia on stunted children aged 6-16 years old, low cognitive function appeared to be significantly linked, compared to normal children. [11] The same result was found in a study conducted by Picauly inKupang and East Sumba, East Nusa Tenggara. [12]

Based on those backgrounds, the author is interested to conduct a study to find out thedifference of cognitive score in children aged 10-12 years from normal and stunted groups. This age is the early adolescent period, where cognitive development markedly increases, thus, they have the capability to link a series of events and express it verbally or symbolically. This stage is called concrete operation, according to Piaget. Pangandaran district was chosen as research location-a district developed in 2012, at the South Beach of West Java. The potential resources came from the sea, forest, and tourism.

\section{Method}

This cross-sectional analytic research on adolescents of 10-12 years old was conducted on December 2016-March 2017 in Sukajaya village, Cimerak, Pangandaran district, West Java. The location was Cimerak and Sukajaya primary school and IbtadiiyahSukajaya. Sukajaya village is a village located at Cimerak, $17 \mathrm{~km}$ away from Parigi, as the capital of Pangandaran district, West Java province.

Inclusion criteria was adolescent of 10-12 years old, physically healthy, willingful to be enrolledinl the study, and able to read, write, and draw. The exclusion criteria was children with epilepsy, hormonal disorders and syndromes.

We used height measurement tool and body weight measurement tool according to the WHO standard. Data was interpreted using WHO 2007 chart. [13] Cognitive function was measured using Mini Mental Scale Examination, a structured scale consisting of 30 points divided into 7 categories: place orientation (country, province, city, building, and floor), time orientation (year, season, month, day, and date), registration (rapidly repeating 3 words), attention and concentration (consecutively reducing by 7 , starting from 100, or spelling the word WAHYU reversely), memory (memorizing 3 words that were spoken before), language (telling the name of 2 objects, repeating a sentence, reading loudly and understanding a sentence, writing a sentence and following 3-steps order), and visual construction (drawing). MMSE score were give according to the number of points that were done perfectly; lower score indicated poor performance and poor cognitive disturbance. The total score ranged between 0-30 (perfect performance). [14,15]

Mini Mental Scale Examination was performed within 5-10 minutes. This test was constructed to be done easily by all medical personnels or trained personnels, anywhere as long as they have received instructions on how to use it. $[14,15]$ Interpretation of Mini Mental State Examination were normal: 24-30, mild: 18-23, severe: 0-17. [14,15] Anthropometry and MMSE test was performed by a pediatrician.

The comparison of MMSE score between adolescents of normal stature and short stature was analyzed using unpaired t-test, alternatively using Wilcoxon rank-sum test. This study has been approved by Ethical Committee of Health Research of Medical Faculty Universitas Padjadjaran, Bandung, Indonesia.

\section{Results}

There were 199 participants in this study, 55 of which were excluded because of missing/ incomplete data. Of 144 subjects, 99 were with normal stature while 45 were short stature. 
Table 1. Subject Characteristics

\begin{tabular}{|c|c|c|c|c|}
\hline \multirow[b]{2}{*}{ Variable } & \multicolumn{2}{|c|}{ Stature } & \multirow[b]{2}{*}{$\begin{array}{c}\text { Total } \\
(\mathrm{n}=144)\end{array}$} & \multirow[b]{2}{*}{ P value } \\
\hline & $\begin{array}{l}\text { Short Stature } \\
\qquad(\mathrm{n}=45)\end{array}$ & $\begin{array}{l}\text { Normal stature } \\
\qquad(\mathrm{n}=99)\end{array}$ & & \\
\hline \multicolumn{5}{|l|}{ Age (years), frequency (\%) } \\
\hline 10 & $17(38)$ & $49(50)$ & $66(46)$ & \multirow{3}{*}{$0,165^{\$}$} \\
\hline 11 & $13(29)$ & $31(31)$ & $44(31)$ & \\
\hline 12 & $15(33)$ & $19(19)$ & $34(24)$ & \\
\hline \multicolumn{5}{|l|}{ Sex, frequency (\%) } \\
\hline Male & $23(51)$ & $53(54)$ & $76(53)$ & \multirow[t]{2}{*}{$0,787^{\$}$} \\
\hline Female & $22(49)$ & $46(46)$ & $68(47)$ & \\
\hline \multicolumn{5}{|l|}{ School class, frequency (\%) } \\
\hline Grade 4 & $12(27)$ & $16(16)$ & $28(19)$ & \multirow{3}{*}{$0,270^{\$}$} \\
\hline Grade 5 & $14(31)$ & $41(41)$ & $55(38)$ & \\
\hline Grade 6 & $19(42)$ & $42(42)$ & $61(42)$ & \\
\hline Z score BMI-for-age, median (min; max) & $-0,89(-3,59 ; 0,91)$ & $-0,31(-2,47 ; 3,37)$ & $-0,69(-1,13 ;-0,30)$ & $0,001^{*}$ \\
\hline \multicolumn{5}{|l|}{ Nutrition status BMI-for-age, frequency (\%) } \\
\hline Severely wasted & $1(2)$ & $0(0)$ & $1(1)$ & \multirow{5}{*}{$0,003^{\#}$} \\
\hline Wasted & $4(9)$ & $7(7)$ & 11(8) & \\
\hline Normal & $40(89)$ & $71(72)$ & $111(77)$ & \\
\hline Overweight & $0(0)$ & $9(9)$ & $9(6)$ & \\
\hline Obese & $0(0)$ & $12(12)$ & $12(8)$ & \\
\hline
\end{tabular}

"Fisher-Exact test; ${ }^{\$}$ Chi-quadrat test; "Wilcoxon rank sum test.

Table 2. Correlation between stature and cognitive impairment in adolescent

\begin{tabular}{|c|c|c|c|c|c|}
\hline \multirow[b]{2}{*}{ Stature } & \multirow[b]{2}{*}{$\begin{array}{c}\text { Severe } \\
(\mathrm{MMSE}<17)\end{array}$} & \multirow{2}{*}{$\begin{array}{c}\text { Cognitive Impairment } \\
\text { Mild } \\
\text { (MMSE } 17 \text { - 23) } \\
\end{array}$} & \multirow[b]{2}{*}{$\begin{array}{c}\text { Normal } \\
(\mathrm{MMSE} \geq 24)\end{array}$} & \multirow[b]{2}{*}{ Total } & \multirow[b]{2}{*}{ P value } \\
\hline & & & & & \\
\hline Short stature & 1 & 19 & 25 & 45 & $0,002^{\#}$ \\
\hline Normal stature & 5 & 15 & 79 & 99 & \\
\hline Total & 6 & 34 & 104 & 144 & \\
\hline
\end{tabular}

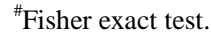

Characteristicsof the study subjects based on the study group is presented on Table 2. The comparison of age, gender, and school class were tested using chi square, comparison of $\mathrm{BMI} / \mathrm{age}$ ( $\mathrm{Z}$ score) was tested using Wilcoxon rank-sum test, while characteristic of BMI/age (nutritional status) was tested using Fischer-Exact test. This table shows that $\mathrm{p}$ value of each characteristic is $>0.05$, thus, the subject characteristics in both short and normal stature groups were homogenous, except the BMI/age ( $Z$ score) group.

There's significant corelation between short stature and cognition disturbances in adolescents $(p=0.002)$. Proportion of MMSE $<24$ was larger in adolescents with short stature compared to those of normal stature.

The median (min; max) score of MMSE in adolescents with short and normal stature was $24(14 ; 30)$ and 27 $(9 ; 30)$. Based on statistical test using Wilcoxon rank-sum test, the median score delta of MMSE result in both groups were significant $(-2.00$, CI 95\% [-3.00;-0.00], $\mathrm{p}=0.013)$.

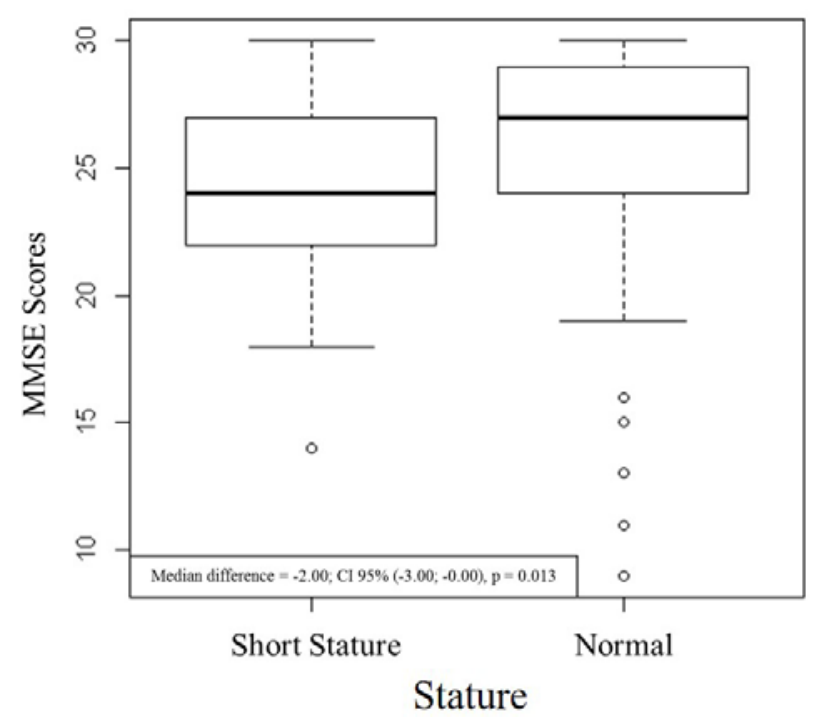

Figure 1. MMSE scores in adolescent with normal and short stature 


\section{Discussion}

The high prevalence of short stature in Indonesia is still a problem for this country. Substantial problems may arise from it. One of which problems is impaired cognition.

Short stature prevalence in this study was $31.25 \%$. It was higher compared to prevalence data available in West Java province 29,2\%. [3] Compared to other countries, Indonesia fell into category with prevalence of $30-39 \%$. Based on Riskesdas 2013, nationally, the short stature prevalence among adolescents was reported 35.1\%. [3] The incidence of short stature between male and female teenage wassimilae.

Cognitive value of short statured adolescents aged 1012 years old was lower compared to those of normal statured adolescents. A study in South Africa on stunted children aged 2 years, after given proper nutrition, resulted in normal body height measurement. However, the outcome of cognition test on children who had history of stunting was worse compared to children without any history of stunting. ${ }^{16}$ Other study in India found that short statured children had poor achievement. It was also reported that despite the correction of nutrition in short statured children, there was no significant difference in cognitive value, even compared with uncorrected short statured children. Short stature not only affect cognitive function, therefore the correction is not enough to improve the cognitive function. [17] Other study in 2013 showed that children aged 6-12 years with significant underweight and short stature had IQ lower than 89. [18]

Other studies demonstrated short statured children had abnormal neuropsychology examination and impaired cognitive function, attention, memory process, visual perception, and verbal comprehension compared to normal children. [19]

A study in South Africa assessing cognitive factors and stunting demonstrated that there was no significant correlation between stunting and child performance using Vineland Social Maturity Scale (VSMS), but closely and significantly related when using Revised-Denver Prescreening Developmental Questionnaire (R-DPDQ). In conclusion, children with body height under -2 SD had normal performance in daily life and social maturity, but had lower motoric and cognitive skills. A study on children with history of stunting when they were 2 years old, after given proper nutrition, had normal measurement at 5 years old. The outcome demonstrated that children with history of stunting had lower cognitive result using Revised Denver Prescreening Developmental Questionnaire compared to children with no history of stunting. [16]

Adolescents aged 10-12 years with short stature were found to have lower cognitive value, but IQ test would still have to be performed as a standard examination for cognitive function. [20] Nonetheless, MMSE test may be performed as an initial test with large population within short period of time while having sensitivity of $87 \%$ and specificity of $82 \%$. [15,21]

Initially, body mass index (BMI) were thought to affect cognitive function, but after further analysis, BMI has no correlation with cognitive function. Study by Jorien, et al [22] demonstrated that there was no correlation between BMI and cognitive function. In contrast, study by Li et al [23] reported obesity on children were followed by decline of IQ. Longitudinal and cross sectional study from Guxenet al [24] and Gunstad et al [25] demonstrated significant correlation between increased BMI with cognitive function.

Two adolescents with normal stature with extreme or outliers MMSE score were found. This might be caused by other factors such as social problem. In several cases, children in school were found to have below average capability, but due to social and psychological factors, school authority permitted the children to remain in public school.

The limitation of this study was that there were no data of body weight and length at birth andat 2 years old. Other matters such as children's unavailable nutritional data, parents' education and income, and education received outside the school, might affectthe study outcome.

Inadequate nutrition can affect some parts of brain that control cognitive, memories, and motoric function. Less protein in the first 2 years of life might affect the development of brain structure and function, also cognitive function. Micronutrient deficiencies such as iron, iodine, and folic acid interfere the cognitive function especially brain development. Other deficiencies such as vitamin A and zinc enhance morbidity by increasing number of child not attending school, decreasing learning ability, and achievement in school. Iron deficiency can cause anemia, therefore it can be a significant factor for low cognitive function. [26]

Low cognitive outcome on short statured adolescents may affect other problems, among others are low self esteem, difficulties in getting job or higher education. Therefore these adolescents need to be given proper education for better self esteem. [27]

\section{Conclusion}

There were significantly different results of this study in cognitive impairment screening in adolescents aged 1012 years between normal and short stature. The result of cognitive impairment screening in short statured adolescents aged 10-12 years was lower compared to those of normal stature adolescents.

\section{Acknowledgements}

We would like to thank Kurnia Wahyudi, M.D.,MSc. from The Biostatistic Divison, Public Health Department, Faculty of Medicine, Universitas Padjadjaran for his helpful discussions and valuable input.

\section{References}

[1] Soetjiningsih. Tumbuh kembang remaja dan permasalahannya, editor. Jakarta: Sagung Seto; 2010; 53-7.

[2] Soetjiningsih. Tumbuh kembang janin dalam kandungan. Dalam: Soetjiningsih, Ranuh G, editor. Tumbuh Kembang Anak. Jakarta: EGC; 2013:73-9.

[3] Riset Kesehatan Dasar 2013. Jakarta: Badan Penelitian dan Pengembangan Kementerian Kesehatan RI; 2013.

[4] WHO.int. Child Malnutrition: Underweight, stunting, wasting and overweight [Internet]. 2016 [cited 2016 Sept 18]. Available from http://apps.who.int/

nutrition/landscape/help.aspx?menu=0\&helpid=391\&lang=EN. 
[5] Nandy S, Irving M, Gordon D, Subramanian SV, Smith GD. Poverty, child under nutrition and morbidity: new evidence from India. Bull WHO. 2005; 83: 210-16.

[6] McDonald CM, Olofin I, Flaxman S, Fawzi WW, Spiegelman D, Caulfield LE, et al. The effect of multiple anthropometric deficits on child mortality: meta-analysis of individual data in 10 prospective studies from developing countries. Am J Clin Nutr. 2013; 97: 896-901.

[7] Rachmi CN, Agho KE, Li M, Baur LA. Stunting, Underweight and Overweight in childrenaged 2.0-4.9 years in Indonesia: Prevalence Trends and Associated Risk Factors. journalpone. 2016: $1-17$.

[8] Kementerian Kesehatan RI. Infodatin Pusat Data dan Informasi Kesehatan: Situasi Balita Pendek. 2016.

[9] Prendergast A, Humphrey J. The stunting syndrome in developing countries. Paediatrics and International Child Health. 2014; 34 250-65.

[10] Martorell R, Zongrone A. Intergenerational influences on child growth and undernutrition. Paediatr Perinat Epidemiol. 2012; 26(suppl 1): 302-14.

[11] Perignon M, Fiorentino M, Kuong K, Burja K, Parker M, Sisokhom S. Stunting, poor iron status and parasite infection are significant risk factors for lower cognitive performance in Cambodian school-aged children. PLOS ONE. 2014; 9(11).

[12] Picauly I, Toy S. Analisis determinan dan pengaruh stunting terhadap prestasi belajar anak sekolah di Kupang dan Sumba Timur, NTT. Jurnal Gizi dan Pangan.8: 55-62.

[13] Mercedes de Onis,a Adelheid W Onyango,a Elaine Borghi,a Amani Siyam,a Chizuru Nishidaa \& Jonathan Siekmanna. Development of a WHO growth reference for school-agedchildren and adolescents. Bulletin of the World Health Organization, September 2007, 85 (9) 661-7.

[14] Folstein M, Folstein S, McHugh P. "Mini-Mental State." A practical method for grading the cognitive state of patients for the clinician. J Psychiatr Res 1975; 12: 189-98.

[15] Crum R, Anthony J, Bassett S, Folstein M. Population-based norms for the Mini-Mental State Examination by age and education level. JAMA. 1993; 269: 2420-1.
[16] Casale D, Desmon C. Recovery from stunting and cognitive outcomes in young children: Evidence from the south african birth to twenty cohort study. Journal of Developmental Origins of Health and Disease. 2016;7:2163-171.

[17] Sokolovic N, Selvam S, Srinivasan K, Thankachan P, Kurpad A, Thomas T. Catch-up growth does not associated with cognitive development in Indian school-age children. European Journal of Clinical Nutrition. 2014; 68(1): 14-8.

[18] Sandjaja, Poh B, Rojroonwasinkul N, Le NBK, Budiman B, Ng L. Relationship between anthropometric indicators and cognitive performance in Southeast Asian school-aged children. British Journal of Nutrition. 2013; 110: S57-S64.

[19] Kar BR, Rao SL, Chandramouli BA. Cognitive development in children with chronic protein energy malnutrition. Behavioral and Brain Functions 2008, 4:31. 2008;4(31):1-12.

[20] Caruso, J. Reliable Component Analysis of the Stanford-Binet: Fourth Edition for 2-6-Year Olds.Psychological Assessment13, no 2. 2001: p827-40.

[21] Ouvrier R, Goldsmith R, Ouvrier S, Williams I. The value of the Mini-Mental State Examination in childhood. A preliminary study. J Child Neurol 1993; 8: 145-48.

[22] VeldwijkJ. Scoltens S, Hornstra G, Bemelmans WJE. Body Mass Index and Cognitive Ability of Young Children. Obes Facts. 2011

[23] Li X. A study of intelligence and personality in children with simple obesity. Int J ObesRelatMetabDisord 1995; 19: 355-7.

[24] Guxens M, Mendez MA, Julvez J, Plana E, Forns J, Basagana X, Torrent M, Sunyer J. Cognitive function and overweight in preschool children. Am J Epidemiol, 2009, 170: 438-46.

[25] Gunstad J, Spitznagel MB, Paul RH, Cohen RA, Kohn M, Luyster FS, Clark R, Williams LM, Gordon E. Body mass index and neuropsychological function in healthy children and adolescents. Appetite 2008; 50: 246-51.

[26] Neumann C, Murphy S, Gewa C, Grillenberger M, Bwibo N. Meat supplementation improves growth, cognitive, and behavioral outcomes in Kenyan children. Journal of Nutrition. 2014; 137: 1119-23.

[27] WHO. World Health Assembly (WHA). Global Nutrition Targets 2025: Stunting Policy Brief. 2014 